\title{
IDENTIFIKASI GEJALA PERUBAHAN IKLIM DI KOTA BANDAR LAMPUNG BERDASARKAN DATA IKLIM MAKRO TAHUN 1998- 2020
}

\author{
Fennidya Nur Pratiwi ${ }^{1}$, Adnin Musadri Asbi2, Nela Agustin Kurnianingsih ${ }^{3}$ \\ 1,2,3Program Studi Perencanaan Wilayah dan Kota Institut Teknologi Sumatera \\ Email : ${ }^{1}$ fennidyanur@gmail.com, ${ }^{2}$ adnin.asbi@pwk.itera.ac.id, ${ }^{3}$ \\ agustin.kurnianingsih@pwk.itera.ac.id
}

\begin{abstract}
Climate change today is an important thing that can affect people's lives and development in the future. For this reason, each stakeholder needs to prepare a strategic program in dealing with the phenomenon of climate change in order to reduce the impact it will cause. In this case of the program, it is important for stakeholders to know how the climate conditions in the area they cover. This study aims to identify the symptoms of climate change that occur in Bandar Lampung City based on two indicators, namely: Pattern of Changes in Air Temperature; Rainfall Change Pattern; and historical events related to climate change. This research was conducted using a qualitative approach with multiple linear regression method and a qualitative approach with a descriptive narrative method. The results of this study indicate that the city of Bandar Lampung in the last \pm 23 years has experienced symptoms of climate change in the form of changes in rainfall patterns and air temperature as well as the impacts of climate change such as the phenomenon of tidal flooding.
\end{abstract}

Keywords: Climate Change, Coastal Region, Macro Climate

\begin{abstract}
ABSTRAK
Perubahan iklim saat ini merupakan hal penting yang dapat mempengaruhi kehidupan masyarakat dan pembangunan di masa yang akan datang. Untuk itu setiap stakeholder perlu mempersiapkan berbagai strategi program dalam menghadapi fenomena perubahan iklim guna mengurangi dampak yang akan ditimbulkan. Dalam hal penentuan program tersebut, maka penting bagi stakeholder untuk mengetahui bagaimana kondisi iklim pada wilayah yang mereka naungi. Penelitian ini bertujuan untuk mengindentifikasi gejala perubahan iklim yang terjadi di Kota Bandar Lampung berdasarkan dua indikator yaitu: Pola Perubahan Suhu Udara; Pola Perubahan Curah Hujan; serta sejarah kejadian yang berkaitan dengan perubahan iklim. Penelitian ini dilakukan dengan menggunakan pendekatan kualitatif dengan metode regresi linier berganda dan pendekatan kualitatif dengan metode deskriptif naratif. Hasil penelitian ini menunjukkan bahwa KotaBandar Lampung dalam kurun waktu \pm 23 tahun terakhir mengalami gejala dari perubahan iklim berupa perubahan pola curah hujan dan suhu udara serta dampak-dampak dari perubahan iklim seperti fenomena banjir rob.
\end{abstract}

Kata kunci: Iklim Makro, Perubahan iklim, Wilayah Pesisir 


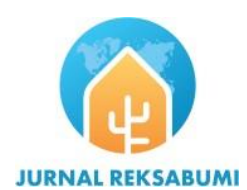

P-ISSN: 0000-0000 dan E-ISSN: 0000-0000

Volume 1 Nomor 1, Bulan Tahun, 01-22

JournalHomepage: http://jurnal.ut.ac.id/reksabumi

https://doi.org/10.33830/Reksabumi.v1i1.2195.2022

\section{PENDAHULUAN}

Perubahan iklim saat ini merupakan hal penting yang dapat mempengaruhi kehidupan masyarakat dan pembangunan di masa yang akan datang (Setiadi, 2018). Isu tersebut akan dapat mempengaruhi pemikiran hampir di semua bidang ilmu termasuk dalam bidang Perencanaan Wilayah dan Kota. Menurut The National Oceanic and Atmospheric Administration (NOAA), Perubahan iklim adalah perubahan jangka panjang dalam statistic dari cuaca (termasuk rata-ratanya). Sedangkan menurut Badan Meteorologi, klimatologi, Geofisika (BMKG, 2011) perubahan iklim merupakan fenomena yang terjadi dalam kondisi alamiah yang secara alami mengalami perubahan (rata-rata) atau ketidaknormalan pada kebiasaan, yang dapat mengganggu perilaku hidup manusia dan aktivitas biologis lainnya. Jika mengacu pada definisi baku Intergovernmental Panel on Climate Change (IPCC) yang tertuang dalam (Aldrian, 2011), menyebutkan bahwa perubahan iklim didasari oleh kejadian yang dialami dalam periode waktu diatas 30 tahun. Selain itu, beberapa variabel perubahan iklim juga berlangsung dalam periode yang relatif lama dengan rentang waktu diatas 20 tahun sehingga tidak mudah untuk menjelaskan adanya indikasi perubahan iklim. Oleh karenanya, setidaknya terdapat empat indikator yang dapat digunakan untuk menjelaskan adanya perubahan iklim pada suatu wilayah menurut IPCC, yaitu:

1. Perubahan Suhu;

2. Peningkatan Curah Hujan Ekstrem.

3. Maju Mundurnya Musim; Serta

4. Perubahan Jumlah Volume Hujan.

Gejala terjadinya perubahan iklim sendiri telah dirasakan oleh masyarakat wilayah pesisir Kota Bandar Lampung sejak beberapa tahun terakhir. Gejala tersebut meliputi kenaikan suhu bumi, naiknya permukaan air laut, perubahan kelembaban udara, curah hujan serta perubahan kecepatan angin (BPLH Kota Bandar Lampung, 2009). Kota Bandar Lampung merupakan kota yang termasuk kedalam 3 kriteria yang memiliki risiko tinggi terhadap dampak dari perubahan iklim (IImi, Asbi, \& Syam, 2021). Menurut hasil penelitian yang dilakukan oleh PPGT dan Perhimpi Provinsi Lampung tahun 2013, Kota Bandar Lampung memiliki tingkat risiko iklim dengan nilai sensitivitas yang cukup tinggi. Hal tersebut disebabkan akibat kurangnya pemahaman masyarakat terhadap kondisi iklim saat ini (Manik, Syaukat, Fauzan, \& Indratmoko, 2013).

Fenomena perubahan iklim dapat memberikan dampak bagi masyarakat dan lingkungan diantaranya yaitu penurunan ketahanan pangan, keanekaragaman bahari berkurang, juga dapat menyebabkan peningkatan kejadian bencana seperti banjir, longsor, kekeringan dan kurangnya ketersediaan air bersih. Sedikitnya 14 kelurahan di Kota Bandar Lampung yang memiliki tingkat kerentanan yang relatif tinggi dari dampak perubahan iklim seperti bencana banjir rob dan banjir bandang (Ilmi, Asbi, \& Syam, 2021). Wilayah pesisir Kota Bandar Lampung memiliki tingkat kerentanan terhadap banjir sedang, dengan bancana banjir yang disebabkan oleh kenaikan permukaan air laut yang merupakan salah satu dampak dari perubahan iklim (Wibisono \& Asbi, 2020). Gunamendukung pernyataan tersebut, maka penelitian ini bertujuan untuk mengindentifikasi 


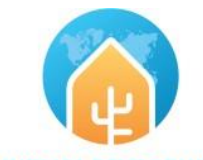

JURNAL REKSABUMI

P-ISSN: 0000-0000 dan E-ISSN: 0000-0000 Volume 1 Nomor 1, Bulan Tahun, 01-22

JournalHomepage: http://jurnal.ut.ac.id/reksabumi

http://doi.org/10.33830/Reksabumi.v

$1 \mathrm{i} 1.2195 .2021$

gejala perubahan iklim yang terjadi di Kota Bandar Lampung berdasarkan tiga indikator yaitu:

1. Perubahan suhu udara;

2. Perubahan curah hujan; serta

3. Sejarah kejadian yang berkaitan dengan perubahan iklim.

Dalam hal ini, data iklim yang digunakan pada penelitian ini termasuk kedalam kategori iklim makro. Menurut Imran,M (2021) iklim makro adalah suatu kondisi iklim pada wilayah dalam lingkup yang luas berdasarkan luasan wilayah minimal $10 \mathrm{~km}^{2}$. Sedangkan menurut Kartasapoetra (1986) iklim makro merupakan keseluruhan kejadian meteorologis khusus di atmosfir yang juga dipengaruhi oleh kondisi topografi bumi dan perubahanperubahan peradaban dipermukaannya yang berhubungan dengan ruang yang besar seperti negara, benua, dan lautan.

\section{METODE PENELITIAN}

Penelitian ini bertujuan mengidentifikasi gejala perubahan iklim yang terjadi di Kota Bandar Lampung. Dalam hal ini peneliti menggunakan data dalam kurun waktu 23 tahun. Penelitian ini berlokasi pada wilayah Kota Bandar Lampung dengan fokus membahas kejadian yang berada di pesisir Kota Bandar Lampung. Sebagai kota yang berbatasan langsung dengan perairan Teluk Lampung, maka wilayah pesisir Kota Bandar Lampung akan cenderung lebih merasakan dampak yang ditimbulkan dari adanya fenomena perubahan iklim. Berikut merupakan peta administrasi dari Kota Bandar Lampung :

\section{Gambar 1. Peta Administrasi Kota Bandar Lampung}

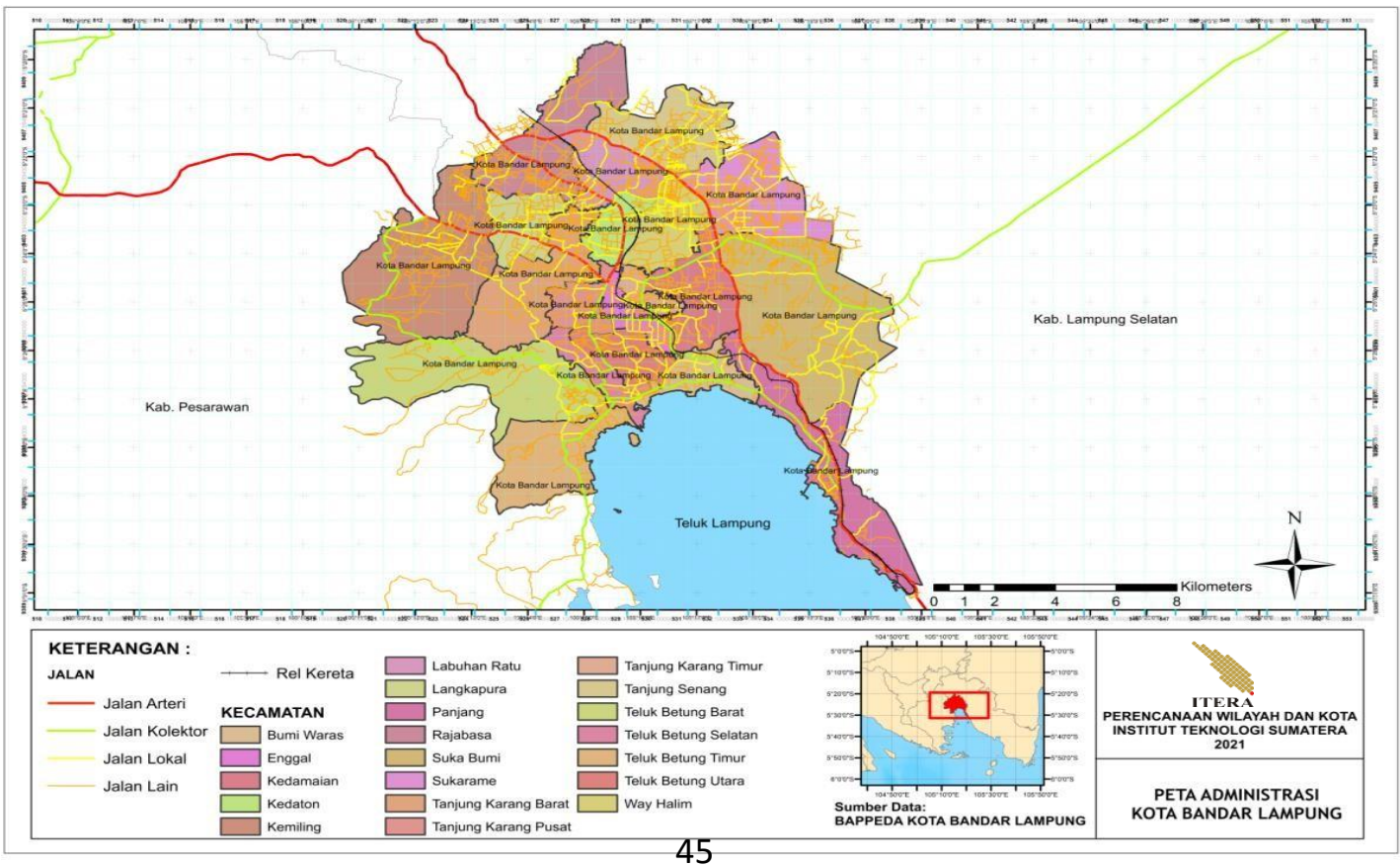




\section{난) \\ JURNAL REKSABUMI}

P-ISSN: 0000-0000 dan E-ISSN: 0000-0000

Volume 1 Nomor 1, Bulan Tahun, 01-22

JournalHomepage: http://jurnal.ut.ac.id/reksabumi

http://doi.org/10.33830/Reksabumi.v

$1 \mathrm{i} 1.2195 .2021$

\section{Sumber: Hasil Olahan Peneliti, 2021}

Penelitian ini dilakukan dengan menggunakan pendekatan Mix Method. Pendekatan ini dipilih karena dalam penelitian ini digunakan berbagai jenis data dan metode analisis baik kualitatif maupun kualitatif. Menurut Musianto (2002), pendekatan kuantitatif merupakan pendekatan yang dalam proses penyusunan data hingga penulisannya mempergunakan aspek pengukuran, perhitungan, rumus dan kepastian data numeric. Sedangkan pendekatan kualitatif merupakan pendekatan yang dalam proses penyusunan data sampai dengan penulisannya mempergunakan aspek-aspek kecenderungan, non perhitungan numerik, situasional deskriptif, interview mendalam, analisis isi, bola salju dan story (Musianto, 2002) Penelitian ini menggunakan beberapa data, baik merupakan data primer maupun data sekunder dari berbagai sumber. Adapun proses pengumpulan data dilakukan dengan cara:

\section{a. Wawancara}

Kegiatan ini dilakukan guna mendapatkan informasi terkait gejala perubahan iklim berdasarkan sudut padang dari masyarakat. Narasumber dalam wawancara ini merupakan masyarakat yang tinggal pada lokasi penelitian dengan durasi minimal 23 tahun yang berjumlah tiga orang. Pertanyaan yang diajukan kepada narasumber adalah pertanyaan yang berkaitan dengan perubahan iklim seperti gejala yang dialami masyarakat, dampak dari fenomena tersebut, sampai dengan kegiatan

\section{b. Observasi} penanggulangan dampak dari fenomena tersebut.

Metode observasi ini digunakan untuk memperoleh informasi yang lebih akurattentang kondisi, situasi, dan masalah yang ada, serta untuk membandingkan atau mencocokkan data dari instansi dengan kondisi lapangan yang sebenarnya.

Selain itu, beberapa data juga didapatkan melalui dokumen-dokumen seperti peraturan, kebijakan pemerintah, atau dokumen lain yang memberikan gambaran tentang wilayah studi. Data sekunder dapat diperoleh dari perpustakaan, teks akademik, instansi pemerintah, dan media internet. Kemudian, data-data yang telah didapatkan diolah dengan menggunakan berbagai teknik analisis. Berikut merupakan penjelasan mengenai teknik analisis yang digunakan dalam mengidentifikasi gejala perubahan iklim yang terjadi di Kota Bandar Lampung;

\section{a. Regresi Linier Berganda}

Uji regresi linier berganda dilakukan untuk mengetahui arah hubungan diantara variabel independen dengan variabel dependen. Dalam melakukan uji regresi linier berganda pada data curah hujan dan suhu udara maka terdapat beberapa tahapan yang perlu dilakukan, yang pertama yaitu melakukan pengelompokan data kedalam lima kelompok berdasarkan periode waktu (8 tahun) dengan menggunakan prinsip single moving average, pengelompokan ini dilakukan guna menentukan baseline dari curah hujan dan suhu udara dalam mengidentifikasi adanya perubahan trend 
JournalHomepage: http://jurnal.ut.ac.id/reksabumi

http://doi.org/10.33830/Reksabumi.v

$1 \mathrm{i} 1.2195 .2021$

curah hujan dan suhu udara dalam periode waktu tertentu. kemudian yang kedua melakukan uji regresi linier berganda dengan persamaan sebagai berikut:

$$
Y=a+b_{1} X_{1}+b_{2} X_{2}+\ldots . .+b_{n} X_{n}
$$

\section{b. Deskriptif Naratif}

Analisis naratif merupakan sebuah paradigma yang mengumpulkan deskripsi dari suatu peristiwa atau kejadian dan kemudian disusun menjadi suatu cerita yang memiliki alur cerita (Polkinghorne dalam Mawardi,2018).

\section{PEMBAHASAN}

\section{Perubahan Suhu Kota Bandar Lampung}

Identifikasi perubahan suhu dilakukan dengan menggunakan data time series selama 23 tahun, yaitu dimulai sejak tahun 1998 hingga 2020 yang bersumber dari Badan Meteorologi, Klimatologi, dan Geofisika (BMKG) Stasiun Meteorologi Maritim Panjang. Dalam pengolahan data juga dilihat berdasarkan dua kriteria yaitu perubahan yang terjadi pada suhu dingin (minimum) serta perubahan yang terjadi pada suhu panas (maksimum).

\section{Perubahan Suhu Dingin (Minimum)}

Pada grafik dibawah ini terlihat bahwa dalam kurun waktu 23 tahun terakhir (19982020) terjadi perubahan suhu minimum diluar kebiasaan rata-rata cuaca pada tahun tersebut. Hal ini didukung pula dengan hasil uji regresi dimana didapatkan persamaan regresi yaitu:

Dimana

$$
\begin{gathered}
Y=30.610+0,268 X_{1}-1,193 X_{2}+0,635 X_{3}+0,050 X_{4}-0,073 X_{5} \\
Y=30.610-0,313 X
\end{gathered}
$$

Berdasarkan persamaan yang didapatkan maka dapat dilihat bahwa suhu pada kelompok suhu dingin (minimum) dalam periode waktu 1998 - 2020 mengalami penurunan suhu sebesar $0,313^{\circ} \mathrm{C} /$ tahun.

Tabel 1. Pola Perubahan Suhu Minimum Kota Bandar Lampung

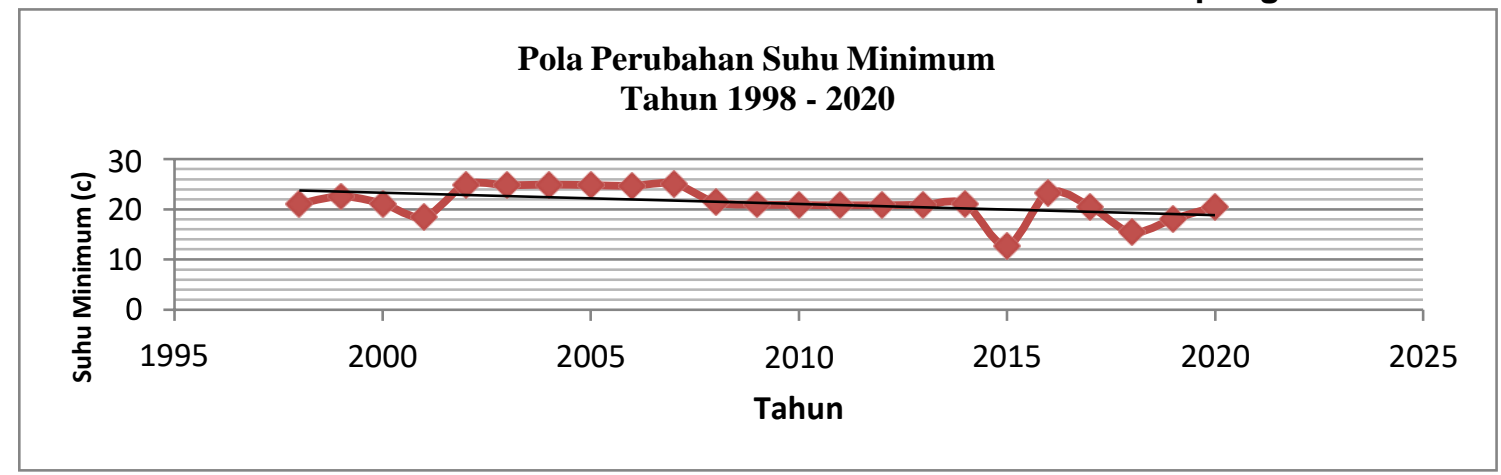

Sumber : Hasil Olahan Data BKMG Stasiun Maritim Panjang, 2021 


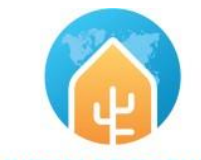

JURNAL REKSABUMI

P-ISSN: 0000-0000 dan E-ISSN: 0000-0000 Volume 1 Nomor 1, Bulan Tahun, 01-22

JournalHomepage: http://jurnal.ut.ac.id/reksabumi

http://doi.org/10.33830/Reksabumi.v $1 \mathrm{i} 1.2195 .2021$

Besaran penurunan suhu tersebut memiliki pola yang sama disetiap periode waktu jika dibandingkan dengan periode normal. Dari hal tersebut maka Kota Bandar Lampung telah menunjukkan adanya gejala perubahan iklim sejak 23 tahun terakhir yang dapat dilihat dari adanya perubahan pada pola suhu minimum yang dialami.

\section{Perubahan Suhu Panas (Maksimum)}

Pada grafik dibawah ini terlihat bahwa dalam kurun waktu 23 tahun terakhir (19982020) terjadi perubahan suhu maksimum di luar kebiasaan rata-rata cuaca pada tahun tersebut. Hal ini didukung pula dengan hasil uji regresi yaitu:

$$
\begin{gathered}
Y=188.486-0.867 X_{1}-1.471 X_{2}-2.307 X_{3}-0.087 X_{4}-0.420 X_{5} \\
Y=188.486-5,152 X
\end{gathered}
$$

Dimana : $Y=$ suhu $X=$ tahun

Berdasarkan persamaan yang didapatkan maka dapat dilihat bahwa suhu pada kelompok suhu panas (maksimum) dalam periode waktu 1998 - 2020 mengalami penurunan suhu sebesar $5,152^{\circ} \mathrm{C} /$ tahun.

Tabel 2. Pola Perubahan Suhu Maksimum Kota Bandar Lampung

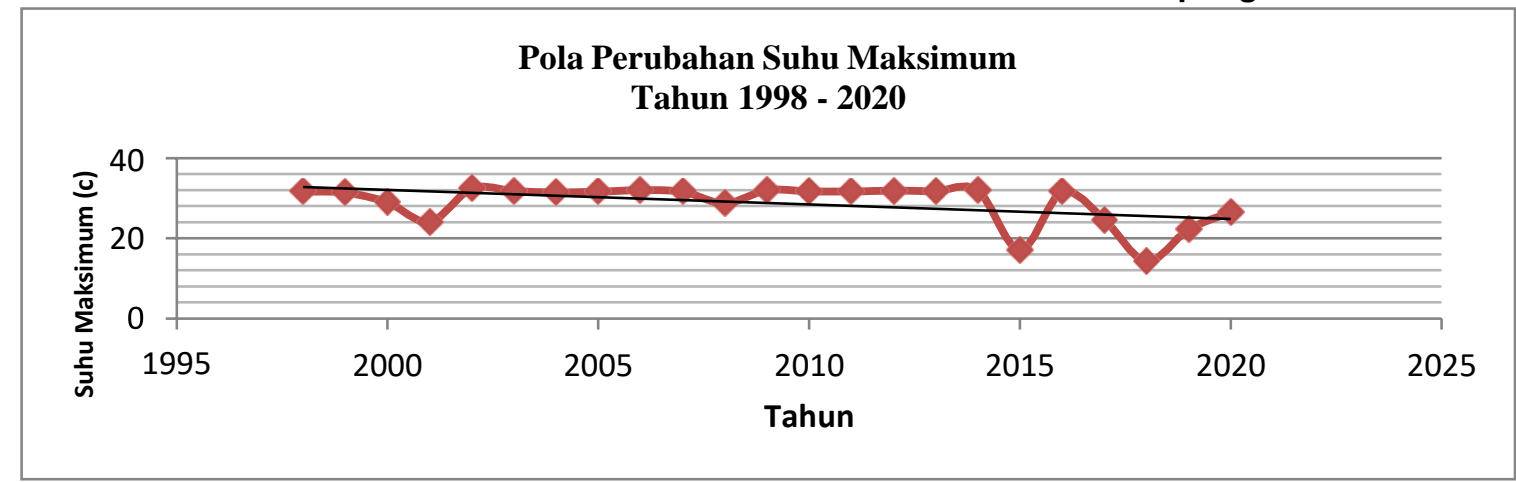

Sumber : Hasil Olahan Data BKMG Stasiun Maritim Panjang, 2021

Perubahan tersebut memiliki pola yang sama pada setiap periode waktu dengan periode normal yang menjadi baseline. Hal tersebut berhasil membuktikan bahwa Kota Bandar Lampung dalam 23 tahun terakhir telah mengalami gejala dari fenomena perubahan iklim berupa perubahan pola suhu maksimum.

\section{Perubahan Curah Hujan Kota Bandar Lampung}

Identifikasi perubahan curah hujan dilakukan dengan menggunakan data time series selama 23 tahun, yaitu dimulai sejak tahun 1998 hingga 2020 yang bersumber dari Badan Meteorologi, Klimatologi, dan Geofisika (BMKG) Stasiun Meteorologi Maritim Panjang. 
URNAL REKSABUMI

P-ISSN: 0000-0000 dan E-ISSN: 0000-0000

Volume 1 Nomor 1, Bulan Tahun, 01-22

JournalHomepage: http://jurnal.ut.ac.id/reksabumi

http://doi.org/10.33830/Reksabumi.v

$1 \mathrm{i} 1.2195 .2021$

Dalam pengolahan data juga dilihat berdasarkan dua kriteria yaitu perubahan yang terjadi pada musim penghujan serta perubahan yang terjadi pada musim kemarau.

\section{Perubahan Curah Hujan di Musim Penghujan}

Pada grafik dibawah ini terlihat bahwa dalam kurun waktu 23 tahun terakhir (19982020) terjadi perubahan curah hujan diluar kebiasaan rata-rata curah hujan pada musim penghujan di tahun tersebut. Hal ini didukung pula dengan hasil uji regresi dimana didapatkan persamaan regresi yaitu:

$$
\mathrm{Y}=362.783+0.035 \mathrm{X}_{1}+0.274 \mathrm{X}_{2}+0.048 \mathrm{X}_{3}-0.793 \mathrm{X}_{4}-0.368 \mathrm{X}_{5}
$$

$$
\mathrm{Y}=362.783-0,804 \mathrm{X}
$$

Dimana $\quad: Y=$ suhu $\quad X=$ tahun

Tabel 3. Pola Perubahan Curah Hujan Musim Hujan Kota Bandar Lampung

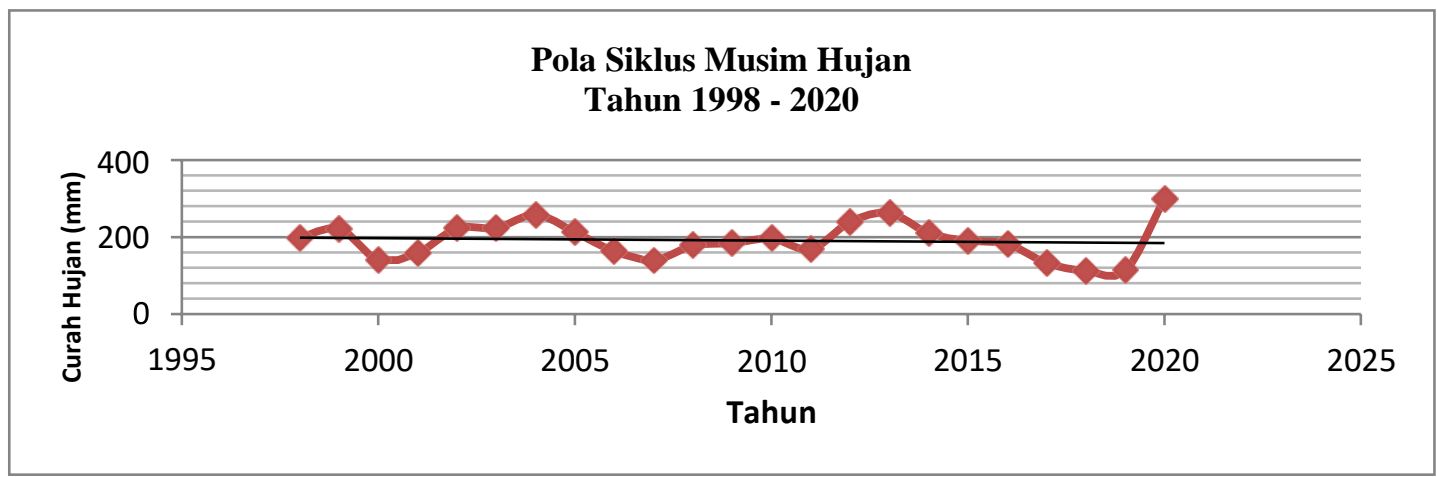

Sumber : Hasil Olahan Data BKMG Stasiun Maritim Panjang, 2021

Berdasarkan hasil tersebut, maka diperoleh informasi bahwa dalam kurun waktu 23 tahun terakhir Kota Bandar Lampung telah menunjukkan adanya gejala perubahan iklim. Gejala tersebut dapat dibuktikan dengan adanya penurunan curah hujan dalam musim penghujan sebesar 0,804 $\mathrm{mm}$ dengan pola perubahan yang berbeda dengan pola perubahan pada periode normal.

\section{Perubahan Curah Hujan di Musim Kemarau}

Pada grafik diatas terlihat bahwa dalam kurun waktu 23 tahun terakhir (1998-2020) terjadi perubahan curah hujan diluar kebiasaan rata-rata curah hujan pada musim kemarau di tahun tersebut. Hal ini didukung pula dengan hasil uji regresi dimana didapatkan persamaan regresi yaitu

$$
\begin{gathered}
Y=66.726+0.063 X_{1}+0.092 X_{2}-0.047 X_{3}+0.177 X_{4}+0.134 X_{5} \\
Y=66.726+0,419 X
\end{gathered}
$$

Dimana : $\mathrm{Y}=$ suhu $\mathrm{X}=$ tahun

Tabel 3. Pola Perubahan Curah Hujan Musim Hujan Kota Bandar Lampung 
JournalHomepage: http://jurnal.ut.ac.id/reksabumi

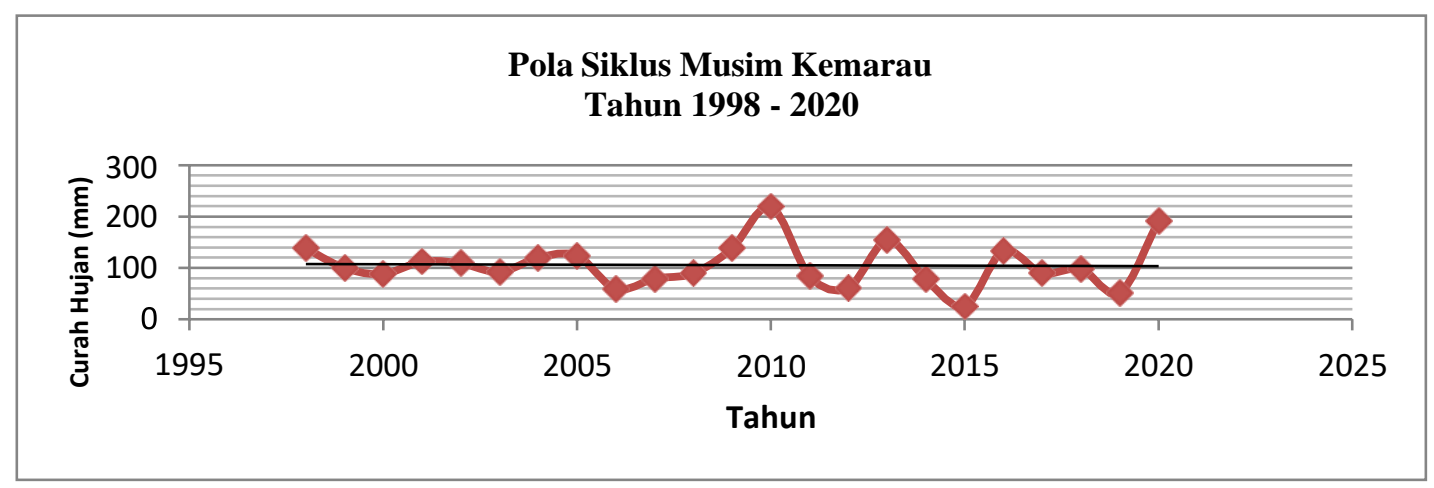

Sumber : Hasil Olahan Data BKMG Stasiun Maritim Panjang, 2021

Berdasarkan hasil tersebut, maka diperoleh informasi bahwa dalam kurun waktu 23 tahun terakhir Kota Bandar Lampung telah menunjukkan adanya gejala perubahan iklim. Gejala tersebut dapat dibuktikan dengan adanya peningkatan curah hujan dalam musim kemarau sebesar $\mathbf{0 , 4 1 9} \mathbf{m m}$ dengan pola perubahan yang berbeda dengan pola perubahan pada periode normal.

\section{Sejarah Kejadian yang Berkaitan dengan Perubahan Iklim.}

Perubahan iklim merupakan bentuk perubahan pada unsur iklim di luar kebiasaan rata-ratanya. Dalam hal ini gejala perubahan iklim dapat diamati dengan melihat adanya perubahan yang terjadi pada tren suhu permukaan dan tren curah hujan. Pada tahun 2010 telah dilakukan penelitian oleh Asian Cities Climate Change Resilience Network (ACCCRN) yang mengidentifikasi tren perubahan iklim Kota Bandar Lampung dalam buku Kajian Kerentanan dan Adaptasi terhadap Perubahan Iklim di Kota Bandar Lampung. Hasil studi (ACCCRN,2010) menyatakan bahwa pada data suhu harian menunjukkan hal yang dapat mengindikasi adanya peningkatan suhu harian terlihat dari semakin tingginya grafik yang dihasilkan. Sedangkan pada tren curah hujan, hasil studi (IPCC,2007 dalam ACCCRN, 2010a) didapatkan bahwa secara keseluruhan curah hujan yang terjadi pada wilayah tropis mengalami tren penurunan. Jika dilihat dari hasil kajian kerentanan (ACCCRN,2010) diperoleh informasi bahwa curah hujan musiman pada wilayah Kota Bandar Lampung mengalami penurunan di semua musim.

Fenomena yang terjadi di Kota Bandar Lampung berdasarkan hasil studi (ACCCRN,2010) juga didukung dengan hasil wawancara yang dilakukan oleh masyarakat yang tinggal pada lokasi studi selama 23 tahun terakhir. Hasil wawancara tersebut menginformasikan bahwa dalam beberapa tahun terakhir masyarakat merasakan adanya peningkatan pada suhu udara. Dari hasil wawancara tersebut juga diperoleh informasi bahwa saat ini salah satu yang menjadi kendala masyarakat yaitu sulitnya memprediksi terjadinya hujan dikarenakan musim penghujan dan kemarau mengalami pergeseran waktu (pancaroba).

Kedua hal yang telah dijelaskan sebelumnya juga memiliki pengaruh terhadap kenaikan permukaan air laut, yang pada waktu tertentu dapat menyebabkan terjadinya bencana banjir rob pada daerah-daerah yang berbatasan langsung dengan bibir pantai. 


\section{난) \\ JURNAL REKSABUMI}

Volume 1 Nomor 1, Bulan Tahun, 01-22

JournalHomepage: http://jurnal.ut.ac.id/reksabumi

http://doi.org/10.33830/Reksabumi.v

$1 \mathrm{i} 1.2195 .2021$

Berdasarkan pencatataan sejarah kejadian bencana pada situs dibi. bnpb.go.id, banjir merupakan bencana yang paling sering terjadi di Kota Bandar Lampung. Sepanjang tahun 2010 hingga tahun 2019, telah terjadi 14 kali banjir dari 26 total kejadian bencana di Kota Bandar Lampung (Agustri \& Asbi, 2020). Bencana banjir rob pada lokasi penelitian terjadi sedikitnya 3 kali dalam satu tahun dengan beberapa rumah yang berdampingan dengan pantai mengalami bencana banjir rob sebanyak $>7$ kali selama setahun (Wibisono \& Asbi, 2020). Bencana banjir rob yang dialami masyarakat pada lokasi penelitian ini pun beragam dengan ketinggan berkisar $<50 \mathrm{~cm}$ hingga mencapai $>3 \mathrm{~m}$ dengan durasi genangan selama lebih dari 6 jam (Wibisono \& Asbi, 2020).

\section{KESIMPULAN}

Kota Bandar Lampung dalam beberapa puluh tahun terakhir telah menunjukkan adanya gejala alam yang merupakan gejala dari perubahan iklim. Berdasarkan hasilanalisis yang telah dilakukan, maka ketiga indikator perubahan iklim telah cukup menguatkan justifikasi bahwa Kota Bandar Lampung telah menunjukkan hal tersebut. Seperti jika dilihat dari perubahan suhu udara dalam 23 tahun terakhir, maka terjadi perubahan pada suhu minimum dan suhu maksimum yaitu penurunan $0,313^{\circ} \mathrm{C} /$ tahun (minimum) dan penurunan $5,152^{\circ} \mathrm{C} /$ tahun (maksimum). Selain itu, curah hujan di Kota Bandar Lampung juga menunjukkan hal yang sama baik pada musim penghujan maupun musim kemarau yaitu penurunan curah hujan 0,804 mm/tahun (musim hujan) dan kenaikan curah hujan 0,419 $\mathrm{mm} /$ tahun (musim kemarau). Hal tersebut juga didukung oleh penelitian terdahulu yang dilakukan oleh ACCCRN tahun 2010 serta berdasarkan hasil wawancara yang dilakukan bersama masyarakat setempat.

\section{UCAPAN TERIMA KASIH}

Penulis mengucapkan terimakasih kepada pihak yang berperan sebagai sumber data, antara lain BMKG Stasiun Maritim Panjang dan Masyarakat Pesisir Kota Bandar Lampung.

\section{REFERENSI}

Agustri, M.P., Asbi, A.M. (2020). Tingkat Risiko Bencana Banjir di Kota Bandar Lampung dan Upaya Pengurangannya Berbasis Penataan Ruang. Jurnal Dialog Penanggulangan Bencana, Vol. 11, No.1.

Aldrian, E. 2011. Adaptasi dan mitigasi perubahan iklim global. Prasetya Online, November $2011,174$.

Anonim. SDGS Indonesia. www.sgd2030indonesia.org diakses pada tanggal 25 Februari 2021 pukul 21.34 WIB

Asian Cities Climate Change Resilience Network (ACCCRN). 2010. Kajian Kerentanan dan Adaptasi terhadap Perubahan Iklim di Kota Bandar Lampung. Bandar Lampung: Publikasi ACCCRN. 
Volume 1 Nomor 1, Bulan Tahun, 01-22

http://doi.org/10.33830/Reksabumi.v 1i1.2195.2021

Badan Perencanaan Pembangunan Nasional. (2010). Indonesia Climate Sectoral Roadmap-ICCSR. Jakarta: Badan Perencanaan Pembangunan Nasional.

Bappeda Provinsi Lampung (2020). Kaji Ulang Rencana Aksi Penurunan Emisi Gas

Rumah Kaca (RAD-GRK) Provinsi Lampung. Provinsi Lampung.

BPLH. 2009. Status Lingkungan Hidup Kota Bandar Lampung. Badan Pengelolaan Lingkungan Hidup.

Ilmi. W.Z., Asbi, A.M., dan Syam. T. (2020). Identifikasi Kapasitas Penganggulangan Pada Kawasan Informal Pesisir Kota Bandar Lampung Dalam Menghadapi Dampak Perubahan Iklim. Jurnal Pengembangan Kota, Volume 8 No. 2 (177-187).

IImi. W.Z., Asbi, A.M., dan Syam. T. (2021) Identifikasi Karakteristik Kawasan Informal Pesisir Kota Bandar Lampung dan Kerentanan Terhadap Dampak Perubahan Iklim. Jurnal Pembangunan Wilayah dan Kota, Vol. 17, No.2, 149-167.

Manik, T. K., Syaukat, S., Fauzan, A., \& Indratmoko, S. (2013). Kajian Kerentanan Dampak Heat Island Studi Kasus Bandar Lampung dan DKI Jakarta. Depok: Fakultas Matematika dan IImu Pengetahuan Alam Universitas Indonesia.

Mawardi, R. 2018. Penelitian Kualitatif dan Penelitian Naratif. Dosen.perbanas.id. Diakses pada Tanggal 04 Januari 2021 pukul 23.21 WIB

Mukhlis, M., Putri, D. M., \& Purnawaty, D. (2011). Strategi Ketahanan Kota Bandar Lampung Terhadap Perubahan Iklim 2011-2030. Bandar Lampung: Asian Cities Climate Change Resilience Network (ACCCRN).

Musianto, L. S. 2002. Perbedaan Pendekatan Kuantitatif Dengan Pendekatan Kualitatif Dalam Metode Penelitian. Jurnal Manajemen Dan Kewirausahaan, 4(2), 123-136. https://doi.org/10.9744/imk.4.2.pp.123-136.

Peraturan Daerah Kota Bandar Lampung Nomor 10 tahun 2011 Tentang Rencana Tata Ruang Wilayah Tahun 2011 - 2030

Saptadi, G., \& Djamal, H. (2018). Jurnal Dialog Penanggulangan Bencana. Jurnal Dialog Penanggulangan Bencana, 3(2), 55-67.

Setiadi, R. 2018. Mengarusutamakan Perubahan Iklim dalam Kurikulum Pendidikan Perencanaan Wilayah dan Kota di Indonesia Mengarusutamakan Perubahan Iklim dalam Kurikulum Pendidikan Perencanaan Wilayah dan Kota di Indonesia. April.

Sitadevi, L. 2017. Membangun Ketahanan Kota terhadap Dampak Perubahan Iklim: Studi Kasus Kota Bandar Lampung. Jurnal Perencanaan Wilayah Dan Kota, 27(3), 190. https://doi.org/10.5614/jrcp.2016.27.3.2

Taylor, J. (2010). Community Based Vulnerability Assesment Semarang and Bandar Lampung, Indonesia. Semarang and Bandar Lampung: ACCCRN and Mercy Corps.

UU No. 1 Tahun. 2014. Pengelolaan wilayah pesisir dan pulau-pulau kecil (management of coastal areas and small islands). http://kkp.go.id/an-component/media/uploadgambar-pendukung/kkp/UUD Nomor 1 2014.pdf 
JURNAL REKSABUMI

P-ISSN: 0000-0000 dan E-ISSN: 0000-0000 Volume 1 Nomor 1, Bulan Tahun, 01-22

JournalHomepage: http://jurnal.ut.ac.id/reksabumi

http://doi.org/10.33830/Reksabumi.v

$1 \mathrm{i} 1.2195 .2021$

Wibisono, W., \& Asbi, A. M. (2020). Strategi Penataan Ruang Berbasis Mitigasi Bencana Berdasarkan Tingkat Kerentanan dan Bahaya Banjir Rob di Kota Bandar Lampung. Jurnal Dialog Penanggulangan Bencana Volume 11, 51- 65. 